\title{
Contact and isolation in hunter-gatherer language dynamics
}

\section{Evidence from Maniq phonology (Aslian, Malay Peninsula $)^{*}$}

\author{
Ewelina Wnuk ${ }^{\mathrm{a}, \mathrm{b}}$ and Niclas Burenhult $\mathrm{t}^{\mathrm{a}, \mathrm{c}}$ \\ ${ }^{a}$ Max Planck Institute for Psycholinguistics / ${ }^{b}$ International Max Planck \\ Research School for Language Sciences / ${ }^{\mathrm{C}}$ Lund University
}

Maniq, spoken by $250-300$ people in southern Thailand, is an undocumented geographical outlier of the Aslian branch of Austroasiatic. Isolated from other Aslian varieties and exposed only to Southern Thai, this northernmost member of the group has long experienced a contact situation which is unique in the Aslian context. Aslian is otherwise mostly under influence from Malay, and exhibits typological characteristics untypical of other Austroasiatic and Mainland Southeast Asian languages. In this paper we pursue an initial investigation of the contrastive strategies of the Maniq sound system. We show that Maniq phonology is manifestly Aslian, and displays only minor influence from Thai. For example, Maniq has not developed tone, register, or undergone changes typically associated with tonogenesis. However, it departs from mainstream Aslian phonology by allowing extreme levels of variation in the realisation of consonants, which in our view are best explained by its distinctive social ecology and geographical isolation.

Keywords: Maniq, Aslian, Austroasiatic, Mainland Southeast Asian languages, phonology, language genealogy, language contact, free variation

\section{Introduction}

The Aslian branch of the Austroasiatic stock is represented by some 18-20 ethnolinguistic groups in Peninsular Malaysia and Isthmian Thailand. This southernmost division of Austroasiatic persists under circumstances very different from those of most of its relatives. Thus, for example, the ecology of all Aslian languages is the evergreen equatorial rainforest, and not the more seasonally marked 
ecologies typical of Mainland Southeast Asia. Second, Aslian speakers have adapted to this tropical environment in a number of distinct and complementary ways. So, although forming a solid, well-defined and geographically rather continuous genealogical grouping, the Aslian languages exist in an unusually diverse societal and economical setting, and are represented among subsistence foragers, slashand-burn horticulturalists, and collectors-traders alike (Benjamin 1985a). Third, unlike their Austroasiatic relatives further north, the Aslian languages are geographically couched well within the Austronesian realm, which is represented in the peninsula primarily by various dialects of Malay.

These circumstances have resulted in a number of both conservative and innovative linguistic characteristics which are conventionally considered to be peculiar to Aslian in the Austroasiatic context (Matisoff 2003). For example, unlike many languages further north, Aslian languages do not adhere to the common pattern of monosyllabism but generally display a large number of sesqui- and disyllabic roots, and frequently also tri- and even tetrasyllabic forms. Furthermore, Aslian languages have untypically productive and regular paradigms of nominal and verbal derivation, employing intricate and presumably conservative morphological processes of reduplication and affixation. Such paradigms and processes have been largely lost or fossilised in other Austroasiatic languages, and they defy the dominant trend of isolating morphology typical of Mainland Southeast Asia. Finally, intense contacts with Austronesian languages, especially Malay, have had a profound influence on the grammars and, above all, the lexica of Aslian languages.

However, the conventional view of Aslian has been challenged by the proposal that some Aslian languages may display unexpected 'Mainland' phonological properties. On the basis of existing accounts of the sound systems of Jahai and, especially, Kensiw, it has been proposed that these languages exhibit contrastive tone, albeit with marginal functional load, and that Kensiw displays a set of aspirated voiceless stops (Hajek 2003; 2010). Both features are suggested to result from contact with Thai. Furthermore, an earlier first-hand source proposed a highly complex set of distinctive vowel qualities in Kensiw, which departs radically from the vowel systems of other Aslian languages (Bishop 1996). These claims are significant because they suggest that the sound systems of a subset of Aslian languages - notably spoken in the northern part of the Aslian range - are currently undergoing substantial reorganisation in response to outside influence.

In this paper we address the issue by examining the sound system in Maniq, a hitherto undescribed Aslian language of the Isthmus of Kra, in southern Thailand. Maniq provides an intriguing exception to the typical Aslian ecology. Spoken by 250-300 subsistence foragers, it is the northernmost Aslian language and currently forms a geographically isolated enclave separated from other Aslian languages by at least 150 kilometres. Its speakers are not in regular contact with other Aslian 
speakers, which is uncommon in the Aslian context. A considerable number of loanwords suggests that Maniq must have been in regular contact with Malay in the past, but this is no longer the case. Presently Maniq is in contact with Southern Thai of the Tai-Kadai stock. This distinguishes Maniq from most other Aslian languages, which are primarily in contact with various dialects of Malay (and in Malaysia also with Standard Malay). Consequently, Maniq provides a unique case for testing to what extent diverging contact ecologies have had an influence on formal language properties in the Aslian context. For example, Maniq can be expected to be the most susceptible to Thai and 'Mainland' influence of all the Aslian languages and thus to any un-Aslian reorganisation of the phonological system.

Our results, detailed below, show that Maniq does indeed display phonological features unusual for Aslian. However, influence from Thai is less in evidence than expected, which suggests instead a hitherto underestimated diversification of sound systems within Aslian itself.

\section{Maniq: An Aslian outlier}

Maniq is spoken by $250-300$ people in the Banthad mountain range of southern Thailand, at the intersection of Trang, Satun, and Phatthalung provinces. ${ }^{1}$ Its speakers are hunter-gatherers traditionally leading a nomadic or a semi-nomadic lifestyle, and they belong to a cluster of forager populations in the Malay Peninsula referred to ethnographically as the Semang. The bands set up temporary camps in the rainforest, usually in relative isolation from the closest settlement. Because of their partial dependence on the local Thai economy (exchange of goods, wage labour, and tourism), the Maniq normally keep the distance short enough to allow regular visits to nearby villages. Almost all Maniq speakers are fluent in Southern Thai, which they use in contact situations with Thai villagers and forestry officials. However, Maniq is the most important language used within the group, and it is learnt as a first language by children (Bishop \& Peterson 2003).

Maniq belongs to the Northern Aslian division of the Aslian branch of the Austroasiatic stock. Until recently, apart from a few word lists and brief notes (Bishop \& Peterson 1993; Bishop \& Peterson 2003; Phaiboon 2006; Becker 2008; Bauer 1991) it was largely undocumented, but in the past few years descriptive work on Maniq has been accumulating (Peterson 2012; Wnuk \& Majid 2014; Kruspe, Burenhult \& Wnuk, in press). Also, recently collected Maniq lexical data form part of our re-examination of Aslian relationships. This shows that Maniq together with Kensiw and Kentaq forms a 'Maniq' subclade of Northern Aslian. This subclade and its sister subclade Menraq-Batek (which includes Jahai, Menriq, and Batek) together form a Maniq/Menraq-Batek grouping, which represents the 


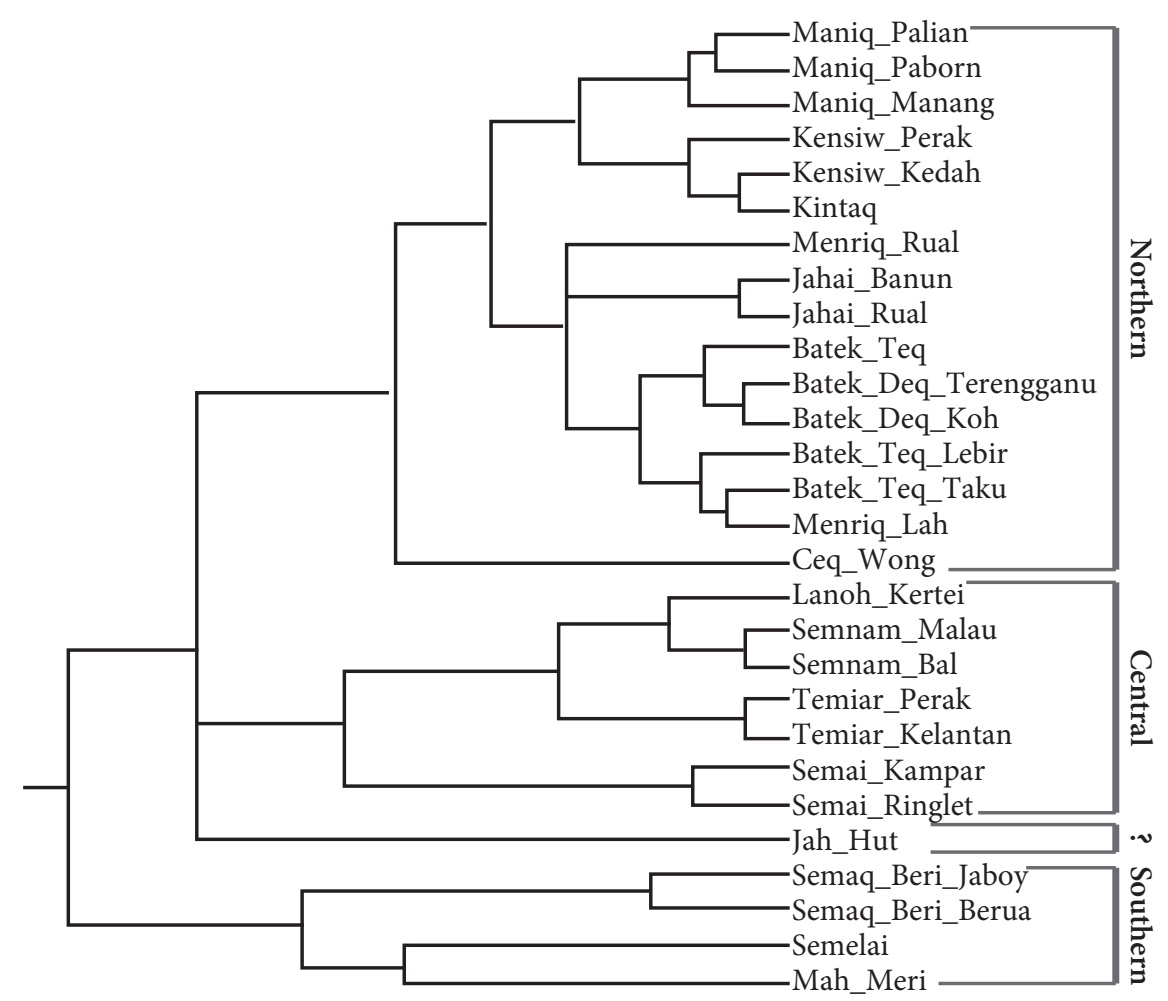

Figure 1. Aslian family tree

portion of Northern Aslian spoken by Semang foragers (Burenhult, Kruspe \& Dunn 2011). Figure 1 illustrates the Aslian family tree derived with computational phylogenetic methods (Dunn et al. 2011).

The 18-20 Aslian languages form a geographically and genealogically distinct branch of Austroasiatic. They are conventionally subdivided into a Northern, Central, and Southern group, but there is increasing evidence that the Jah Hut language forms a separate, fourth branch (Diffloth \& Zide 1992; Dunn et al. 2011; cf. Figure 2).

Maniq is surrounded by the Tai-Kadai stock (represented by Southern Thai) and potentially susceptible to typological and lexical influence very different from that experienced by the rest of Aslian. Since the early 1900s, ethnographic sources have reported that the Maniq community is not in contact with other Aslian communities, a situation discussed and verified by Peterson (2012). Although it has so far remained uncertain to what extent Maniq is structurally distinct, there are clear indications that it has undergone considerable lexical change in relation to much of the rest of Aslian. Thus, according to a recent computational phylogenetic analysis of Aslian basic vocabulary by Dunn et al. (2011), most of the Northern 


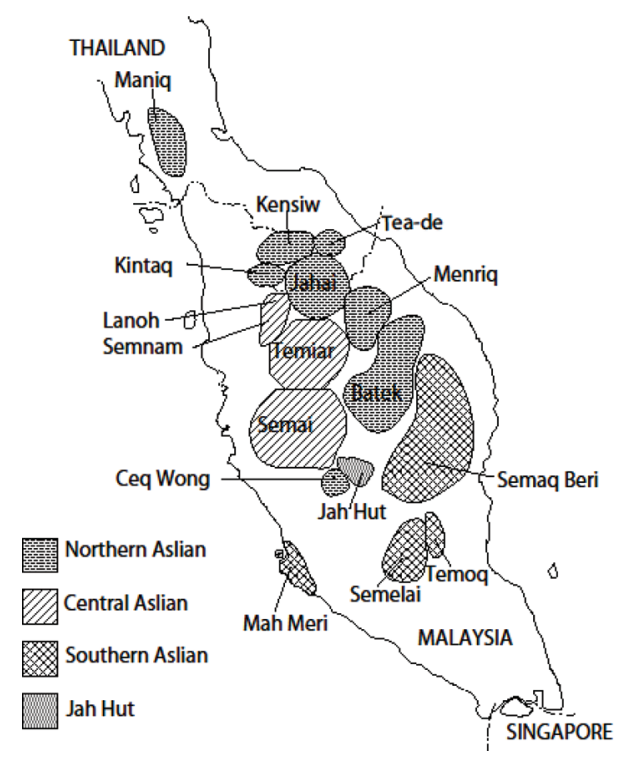

Figure 2. Aslian languages

Aslian division (specifically those Northern Aslian languages which are spoken by foragers, the Maniq/Menraq-Batek clade) is lexically highly divergent from other Aslian branches. Compared to the rest of Aslian these languages have experienced an unusually high rate of change to their basic vocabulary, presumably due to a distinct pattern of intense contact between foraging groups. Notably, among these languages, Maniq displays the greatest divergence and has thus taken lexical change to its extreme. There is little indication that this is due to contact with Southern Thai (i.e. lexical change cannot be shown to result from borrowing of Thai vocabulary). This suggests that the secondary geographical isolation of Maniq has given a further boost to the Northern Aslian trend of lexical diversification.

Identifying the typological profile of Maniq is an important next step in determining to what extent it is different from other Aslian languages and why any such differences have come about. As just noted above, lexical analyses suggest that internal diversification within Aslian overrides divergent external contact situations as the main cause of change, and we might hypothesise that typological features follow a similar trajectory. In the present paper we examine the contrastive strategies of the Maniq sound system. Throughout the analysis, we situate the Maniq data in the wider Aslian (and general Austroasiatic) perspective, as well as make frequent references to relevant features in contact languages, especially Southern Thai. 


\section{Maniq phonology}

This section describes the phonological system of Maniq, including its phonemic inventory of consonants (Section 3.1) and vowels (Section 3.2) and their phonetic realisation, as well as prosodic features (Section 3.3). The analysis is based on a glossary of 2,100 forms, and primarily relies on auditory impression, although selective instrumental analyses have been carried out on some segments.

\subsection{Consonants}

Aslian languages have rather typical Austroasiatic consonant systems. There is a core set of distinctive points and manners of articulation, shared by all Aslian languages described to date and adding up to approximately 20 phonemes (for comparative notes, see Kruspe 2004:58-59). Some languages add further distinctions to this core set. For example, Northern Aslian languages have an augmented fricative series, adding at least a voiceless bilabial / $\phi$ / to the set (see e.g. Bishop 1996; Burenhult 2005; Phaiboon 2006).

Maniq shares these features with its relatives, but has an enlarged system of consonants compared to other Northern Aslian languages, totalling 23 phonemes. This is due to the untypical contrastive function of aspiration in stops resulting in the addition of three extra phonemes to the standard series. However, these additional distinctions are infrequent and display clear restrictions to their phonotactic $^{2}$ and lexical distribution (see further below). A general feature of the Maniq system of consonants is an unusually high degree of realisational variation across environments, instances, and speakers. As will be shown below, this is particularly evident in stops, fricatives, and liquids. Table 1 presents the full inventory of Maniq consonant phonemes.

Table 1. Consonant phonemes in Maniq

\begin{tabular}{llllll}
\hline & bilabial & alveolar & palatal & velar & glottal \\
\hline stop & $\mathrm{b} / \mathrm{p}$ & $\mathrm{d} / \mathrm{t}$ & $\mathrm{f} / \mathrm{c}$ & $\mathrm{g} / \mathrm{k}$ & $\mathrm{r}$ \\
aspirated stop & $\mathrm{p}^{\mathrm{h}}$ & $\mathrm{t}^{\mathrm{h}}$ & & $\mathrm{k}^{\mathrm{h}}$ & \\
nasal & $\mathrm{m}$ & $\mathrm{n}$ & $\mathrm{n}$ & $\mathrm{n}$ & \\
fricative & $\phi$ & & 6 & & \\
rhotic & & & $\mathrm{r}$ & \\
lateral & $\mathrm{l}$ & & & \\
approximant & $\mathrm{w}$ & & $\mathrm{j}$ & & \\
\hline
\end{tabular}




\subsubsection{Stops}

There are 12 stop phonemes in Maniq: the voiceless /p, t, c, k, l/, voiced /b, d, f, g/, and post-aspirated voiceless $/ \mathrm{p}^{\mathrm{h}}, \mathrm{t}^{\mathrm{h}}, \mathrm{k} /$. The latter occur only in a small set of Thai loanwords. The stops in each set are pronounced as bilabial, alveolar, palatal and velar, respectively. The following minimal pairs illustrate contrasts between the voiced and voiceless series in word-initial position:

$\begin{array}{llll}\text { /balì/ } & \text { 'leg' } & \text { /paliz/ } & \text { 'to find' } \\ \text { /dut/ } & \text { 'navel' } & \text { /tut/ } & \text { 'to be empty' } \\ \text { /fec/ } & \text { 'to run' } & / \text { cec/ } & \text { 'to slide' } \\ \text { /gaw/ } & \text { 'pig' } & / \text { kaw/ } & \text { '(proximate marker)' }\end{array}$

Infrequently, voiceless phonemes are realised as phonetically voiced and vice versa (cf. transcription mismatches in Bauer 1991, Bishop \& Peterson 2003, and Phaiboon 2006). All stop phonemes can occur in syllable-initial position, but syllable-finally the manner distinctions are lost and only voiceless non-aspirated stops occur. Final stops are by default unreleased. Stops in words in isolation may

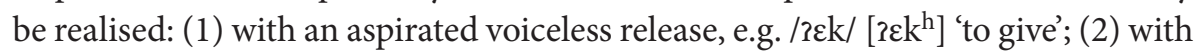
an extra vowel and an optional glottal stop, e.g. /planuk/ [planuk ${ }^{\mathrm{i}}$ ] 'lesser mouse deer (Tragulus kanchil)'; (3) with a voiced nasal release followed by an optional glottal stop, e.g. /garet/ [garet ${ }^{\mathrm{n}}$ ] 'cloth'; (4) with a homorganic fricative release, e.g. /tapip/ [t $\Lambda$ pip $\left.{ }^{\phi}\right]$ 'ashes'. Such patterns of stop release, apart from the last one, are also attested in other Aslian languages - (Burenhult \& Wegener 2009). None of them is lexically contrastive.

3.1.1.1 Non-aspirated stops. The segments /b, p/ are usually realised as bilabial stops. In intervocalic position they are both sometimes pronounced as the bilabial

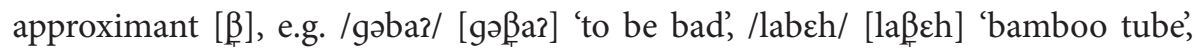
/ləpaj/ [lə_aj] 'fat'. In such cases, the contrast between the voiced and voiceless is neutralised.

The alveolar stops / $\mathrm{t} /$ and /d/ are normally realised as [t] and [d], unless occurring before front close and close-mid vowels /i, e/ or the opening diphthong /ie/. In such environments, they are occasionally realised as affricated stops $\left[t^{\epsilon}, d^{\mathbb{Z}}\right]$,

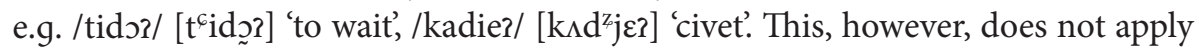
systematically. The palatal stops $/ c, f /$ are realised as simple stops [c, f], e.g. [cej] /cej/ 'bum', [jit] /fit/ 'to obtain food', or affricated stops [c $\left.\mathrm{c}^{\mathrm{c}}, \mathrm{f}^{\mathrm{z}}\right]$, e.g. /kacer/ [kec er] 'moon', /fanat/ [ $f^{z} \Lambda$ nat $]$ 'pineapple'. The two variants are in free variation although the affricated stops are more frequent. Perceptually, they are very similar to the affricated alveolar stops $\left[\mathrm{t}^{\mathrm{\epsilon}}, \mathrm{d}^{\mathrm{z}}\right]$. The affricated release of the palatal stop, however, occurs in the environment of all vowels and is more common than the alveolar stop affrication. If the voiceless palatal stop / $/$ is copied from the final-syllable 
coda, it is often realised as an alveolo-palatal fricative [c] or palatal approximant

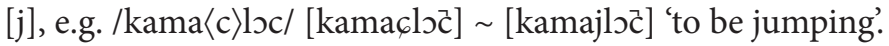

The voiceless velar stop / $\mathrm{k} /$ is a considerably more frequent phoneme than its voiced counterpart $/ \mathrm{g} /$. It also displays much greater allophonic variation. The first varying factor in the allophones of $/ \mathrm{k} /$ is the place of articulation which ranges from velar, e.g. $/ \mathrm{k} \varepsilon n /\left[\mathrm{k \varepsilon}{ }^{\mathrm{d}} \mathrm{n}\right.$ ] 'to get, to take', uvular, e.g. /rikan/ [iiqa ${ }^{\mathrm{d}} \mathrm{n}$ ] 'fish', to epiglottal, e.g. /kuks?/ [quæs?] 'nail'. The uvular and epiglottal allophones occur usually, but not always, in the environment of back vowels, in particular in fast speech. The velar stop / $\mathrm{k} /$ may also be realised as one of the range of dorsal/radical frica-

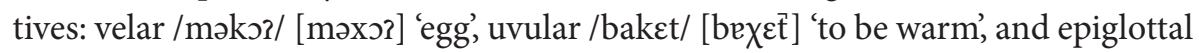
$/ \mathrm{lmk \varepsilon m} /\left[\mathrm{l} m \mathrm{~m}^{\mathrm{b}} \mathrm{m}\right]$ ' to have fever'. Similarly to $/ \mathrm{k} /$, the voiced velar plosive $/ \mathrm{g} /$ has also been recorded to surface as a uvular fricative, e.g. /tigar/ [tisa?] 'three. Finally, in some rare cases, $/ \mathrm{k} /$ is realised as a uvular approximant, e.g. /laka?/ [law̦ar] 'to insert hand'. It may be briefly glottalised, in which case a very short glottal stop interrupts it.

The glottal stop / $/ 2$ is a high-frequency segment found in both onset and coda positions. It is realised as [?]: / $\mathrm{raj} /$ [?aj] 'banded leaf monkey (Presbytis femoralis)', /haiip/ [haitp] 'to know, to remember', /bur/ [bur] 'to drink'. The constriction of the glottis during its production frequently influences adjacent sounds, causing creaky voice, which is a typical co-articulatory effect accompanying glottal stops (Ladefoged \& Maddieson 1996:75). When pronounced with emphasis, the final glottal stop is released with a heavy aspiration, /riciz/ [3ici h'] 'body', similar to the aspirated release of final stops described above. In continuous speech, it is often elided at the end of the syllable.

3.1.1.2 Aspirated stops. The aspirated stops are a marginal phenomenon associated with Thai borrowings. The whole series of aspirated voiceless stops $/ \mathrm{p}^{\mathrm{h}}, \mathrm{t}^{\mathrm{h}}, \mathrm{k}^{\mathrm{h}} /$ is found syllable-initially in a set of 26 Thai loanwords. The following minimal or near-minimal pairs illustrate the distinction.

\begin{tabular}{|c|c|c|c|}
\hline$/ \mathrm{p}^{\mathrm{h}} \mathrm{ak} /$ & $\begin{array}{l}\text { 'vegetable’ } \\
\text { (Thai phàk) }\end{array}$ & /pak/ & 'to slap, to hit' \\
\hline$/ \operatorname{tap}^{\mathrm{h}} \mathrm{an} /$ & $\begin{array}{l}\text { 'bridge' } \\
\text { (Thai sàphaan) }\end{array}$ & /papan/ & '(tree sp.)' \\
\hline$/ \mathrm{t}^{\mathrm{h}} \mathrm{am} /$ & 'cave' (Thai thâm) & $/ \operatorname{tam} /$ & 'place' \\
\hline /hut ${ }^{\text {hiem/ }}$ & $\begin{array}{l}\text { 'garlic' (Southern } \\
\text { Thai hǔa thiam) }\end{array}$ & /tem/ & 'right side' \\
\hline$/ \mathrm{t}^{\mathrm{h}}$ ien/ & 'candle' (Thai thian) & /cantien/ & 'vine, rope' \\
\hline$/ \mathrm{t}^{\mathrm{h}} \mathrm{an} /$ & $\begin{array}{l}\text { 'to catch up' } \\
\text { (Thai than) }\end{array}$ & /nəmtan/ & 'sugar' (Thai námtaan) \\
\hline
\end{tabular}




\begin{tabular}{|c|c|c|c|}
\hline$/$ mant $^{\mathrm{h}} \mathrm{et} /$ & $\begin{array}{l}\text { 'sweet potato' } \\
\text { (Thai manthêet) }\end{array}$ & /katet/ & $\begin{array}{l}\text { 'to blowpipe (using one } \\
\text { thin shaft)' }\end{array}$ \\
\hline$/ \mathrm{k}^{\mathrm{h}_{\mathrm{iew}} / \mathrm{I}}$ & $\begin{array}{l}\text { 'canine tooth' } \\
\text { (Thai khîaw) }\end{array}$ & /kiew/ & '(plant sp.)' \\
\hline$/ \mathrm{k}^{\mathrm{h}}$ anom/ & $\begin{array}{l}\text { 'candy, sweet' } \\
\text { (Thai khànŏm) }\end{array}$ & /kanom/ & 'to urinate' \\
\hline$/ \mathrm{k}^{\mathrm{h}}$ วn/ & $\begin{array}{l}\text { 'hammer' } \\
\text { (Thai khóon) }\end{array}$ & /mankon/ & '(tree sp.)' \\
\hline
\end{tabular}

Other than the listed items, there are some loanwords from Thai for which no contrastive forms have been identified, e.g. $p^{h}$ o 'to be enough', $k^{h} w a n$ 'axe.'

Aspiration in borrowed Thai lexical items is not entirely regular and predictable. There are a number of unaspirated loans with aspirated Thai source terms, e.g. /kanbit/ 'fishing rod' (Thai khanbèt), /kuhəy/ 'pharynx' (Thai khosh วy). They could represent an earlier layer of loanwords with no aspiration or simply indicate that the preservation of aspiration is not systematic. There might also be a dialectal or individual variation in the retention of aspirated stops in Thai loanwords (cf. khshsy 'pharynx/glottis' in Phaiboon 2006).

The palatal aspirated stop $/ \mathrm{c}^{\mathrm{h}} /$ is not in evidence, even though it is part of the Thai inventory. Thai loans in which it would be expected are very rare in the corpus. The current data contains only an affricated palatal stop $\left[c^{6}\right]$ realisation, suggesting the underlying plain palatal stop /c/, e.g. /cet/ [ $\left.\mathrm{c}^{\complement} \varepsilon \vec{t}\right]$ 'to wipe' (Thai chét). One has to bear in mind, however, that $\left[c^{\mathrm{c}}\right]$ and $\left[c^{\mathrm{h}}\right]$ may be difficult to distinguish auditorily. A larger data set will possibly reveal more about the nature of this sound in Maniq, and the future identification of $/ \mathrm{c}^{\mathrm{h}} /$ would not be unexpected.

Aspirated stops have not been found in Malay loanwords, a fact which in itself is not surprising since Malay does not have aspirated stops in its inventory. Yet they do appear in some words of Malay origin in the closely related Kensiw language, e.g. $/ \mathrm{p}^{\mathrm{h}}$ arot $/<$ Malay parut 'scar', as well as in Southern Aslian Mah Meri (Kruspe, personal communication). ${ }^{3}$

Importantly, the aspirated stops are absent from the indigenous lexicon. This is in contrast to the pattern observed in Kensiw, for which at least a velar exponent $/ \mathrm{k}^{\mathrm{h}} /$ is identified in indigenous words, e.g. $/ \mathrm{k}^{\mathrm{h}} \partial \mathrm{r} /$ 'to vomit', $/ \mathrm{k}^{\mathrm{h}} \mathrm{ir} \mathrm{h} /$ 'mountain goat' (Phaiboon 2006; Hajek 2010). Incidentally, these two Kensiw examples correspond to /kər/ 'to vomit' and /kieh/ 'mainland serow (Capricornis milneedwardsii)' in Maniq. However, aspirated bilabial $\left[\mathrm{p}^{\mathrm{h}}\right]$ does occur in indigenous Maniq forms as an allophone of the voiceless bilabial fricative / $\phi$ / (see Section 3.1.3 below). 


\subsubsection{Nasals ${ }^{4}$}

Maniq has four nasals / $m, n, n, y /$ displaying the same places of articulation as the oral stops (except the glottal stop), i.e. bilabial, alveolar, palatal, and velar.

They are realised as $[m, n, n, n]$, unless they are found in word-final position following an oral vowel. In this environment they are realised as prestopped nasals $\left[{ }^{b} \mathrm{~m},{ }^{d} \mathrm{n},{ }^{f} \mathrm{n},{ }^{\mathrm{g}} \mathrm{n}\right]$, a term commonly applied in Aslian descriptive convention (Bishop 1996; Kruspe 2004; Burenhult 2005; Burenhult \& Wegener 2009) to denote allophones of nasals, in which the nasal part is preceded by a voiced stop-like onset, most frequently very short, sometimes hardly audible. ${ }^{5}$

\begin{tabular}{|c|c|c|}
\hline$\left[c^{6} \mathrm{adu}^{\mathrm{b}} \mathrm{m}\right]$ & /cadum/ & 'to embrace, to hold' \\
\hline$\left[c^{6} a^{d} n\right]$ & /can/ & 'foot' \\
\hline$\left[\mathrm{habu}^{\dagger} \mathrm{n}\right]$ & /habup/ & 'to be full' \\
\hline$\left[w \nu^{9} n\right]$ & /won/ & 'child' \\
\hline
\end{tabular}

There is convincing historical and synchronic evidence described for several Aslian phonologies and present in Maniq in favour of treating prestopped nasals as allophones of nasals rather than allophones of voiced stops (e.g. Kruspe 2004; Burenhult 2005). Prestopping of final nasals does not occur in the reduplicated/

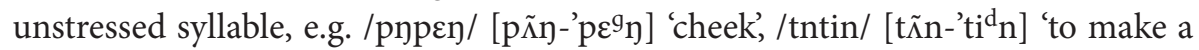
tired sound', /won 'hõ?/ [wõn hõ?] 'little' (from woy 'child') as well as unstressed function words, e.g. personal or demonstrative pronouns. If stressed or uttered in isolation, function words are pronounced with a prestopped nasal: / rin/ [rĩn $2 \mathrm{i}^{\dagger} \mathrm{n}$ ] 'I (1 st person singular)', / / um/ [ $2 \tilde{u} \mathrm{~m} \sim 3 \mathrm{u}^{\mathrm{b}} \mathrm{m}$ ] 'that (distal)'. Prestopping of final nasals does occur, however, after an oral vowel in loanwords, e.g. /picєn/ [pic $\varepsilon^{9}$ n] 'banana' (Malay pisang), / $\mathrm{t}^{\mathrm{h}} \mathrm{am} /\left[\mathrm{t}^{\mathrm{h}} \mathrm{a}^{\mathrm{b}} \mathrm{m}\right]$ 'cave' (Thai thâm).

Simple nasals occur after nasal vowels, e.g. /dagãn/ [dagãn] 'charcoal', as well as vowels progressively nasalised by a nasal consonant onset, e.g. /nam/ [nãm] 'to open fist'. There exists a small number of apparent exceptions, in which progressive nasalisation is presumably blocked: [han $\varepsilon^{9} \mathrm{n}$ ] 'hole, cave', [pani ${ }^{\mathrm{g}} \mathrm{y}$ ] 'resting

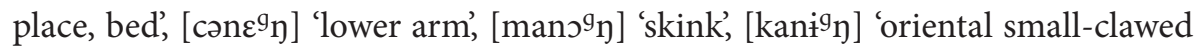
otter (Aonyx cinerea)'. The phonetic representations of these are, however, not stable across different realisations, sometimes being realised with a medial stop preceded by a nasalised vowel or a medial cluster of a stop + nasal, e.g. [cãd $\varepsilon^{9} \mathfrak{n}$ ], [kandì ${ }^{9}$ ] (see also Bishop \& Peterson 2003: 92). Furthermore, the earlier historical stages of these words show medial clusters ${ }^{*}$-nd-and ${ }^{*}-n r$-, still found in their Aslian cognates (Diffloth, personal communication; cf. Maniq [man $\supset^{9}$ n] 'skink' and Jahai [man ${ }^{\mathrm{d}} \mathrm{r}^{9} \mathrm{n}$ ] 'skink'). This leads us to conclude that at the underlying level the consonant clusters are still present (i.e. /handen/, /pandin/, /cənden/, $/ \mathrm{mand}\lrcorner \mathrm{y} / \mathrm{/} / \mathrm{kandin} /$ ) and there is a tendency among some speakers to assimilate them. These items are therefore not true exceptions to progressive nasalisation. In 
fast speech, across word boundaries as well as within the word, nasals assume the place of articulation of the following stop, e.g. /Rin bur/ [2im bu?] 'I drink', /my$\mathrm{d} \varepsilon \mathrm{y} /\left[\mathrm{m} ə \mathrm{n}-\mathrm{d} \varepsilon^{9} \mathrm{n}\right]$ 'to be looking. In some cases of reduplication, the copy of the nasal surfaces as a glottal stop preceded by a nasal vowel, e.g. /hnhan/ [hãrhan] 'to go over a hill'. If the palatal nasal $/ \mathrm{n} /$ in the coda of the reduplicated syllable is followed by another nasal, it sometimes surfaces as a palatal glide /j/, e.g. /haluk nnnan/ [haluk najnan] 'barred gliding lizard (Draco taeniopterus)'.

\subsubsection{Fricatives}

There are three voiceless fricative phonemes in Maniq: bilabial / $\phi /$, alveolo-palatal $/ \varsigma /$, and glottal /h/, all of which are found in both syllable-initial and syllable-final position.

The bilabial fricative is analysed here as having two main allophones: a voiceless bilabial fricative $[\phi]$ in word-final position, and a post-aspirated bilabial stop

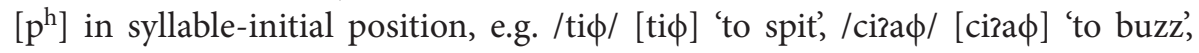
$/ \phi \mathrm{p} \phi \supset \mathrm{p} /\left[\mathrm{p}^{\mathrm{h}} \mathrm{ap}{ }^{\mathrm{h}} \supset \mathrm{p}\right]$ 'to make a sound (of Pallas' squirrel (Callosciurus erythraeus)), / $\supset \supset \phi \supset \mathrm{y} /\left[\mathrm{p}^{\mathrm{h}} \supset \mathrm{mp}^{\mathrm{h}} \supset \mathrm{n}\right]$ 'to make a low-pitched sound'. The sound occurs in the coda of the pre-final syllable only in reduplicated forms. In this environment, it is realised as a vague and brief fricative noise whose phonetic properties are unclear,

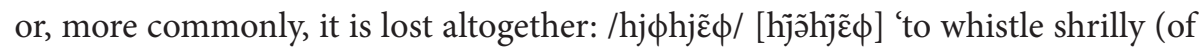
birds)'.

A bilabial fricative is attested in most Northern Aslian languages, but only in syllable-final position. Its occurrence in syllable-initial position is thus unique to Maniq. It might be argued that the initial $\left[\mathrm{p}^{\mathrm{h}}\right]$ should be analysed as the aspirated stop $/ \mathrm{p}^{\mathrm{h}} /$, a phoneme whose identical syllable-initial realisation is already attested in vocabulary borrowed from Thai (cf. Section 3.1.1.2). However, the only aspirated stop found to occur in indigenous vocabulary is the bilabial $\left[\mathrm{p}^{\mathrm{h}}\right]$, so, if we disregard Thai loanwords for the moment, the most parsimonious analysis is one which treats the fricative $[\phi]$ and aspirated $\left[\mathrm{p}^{\mathrm{h}}\right]$ as allophones of one underlying phoneme in indigenous forms. This is justified by the phonetic similarity between these realisations (both are voiceless bilabial aspirates) as well as semantics. The majority of $/ \phi /$-final words and $\left[\mathrm{p}^{\mathrm{h}}\right]$-initial indigenous words have an onomatopoeic component, conveying meanings associated with processes and actions involving motion of air, e.g. /lĩ $\phi /$ 'to breathe', / /eф/ 'to blow', / $\phi$ up $\phi$ up/ 'to flap wings briskly', / $\phi i k$ / 'to smash, to hit'.

The alveolo-palatal fricative in Maniq displays considerable variation across speakers and occurrences. It is most commonly realised as the alveolo-palatal fricative $[6]$, and less often as the palatal fricative [ç], an alveolar fricative $[s]$, or as an affricate [ts] or [tc]. A marginal allophone is the aspirated palatal stop [ $\left.\mathrm{c}^{\mathrm{h}}\right]$ which occurs occasionally in Thai loans (see Section 3.1.1.2). Affricate realisations 
tend to occur in the onset of stressed syllables, e.g. / $60 \mathrm{k} /[\mathrm{t} \sigma \mathrm{k}]$ ' hair'. In cases of coda copying, the copy of $/ \zeta /$ is sometimes realised as an approximant [j], e.g.

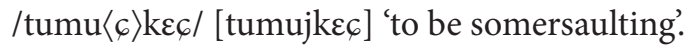

The glottal fricative $/ \mathrm{h} /$ is most often realised as a voiceless glottal [h], although a range of other realisations occur. Among voiceless non-glottal fricative allophones of /h/ we find a velar [x], e.g. /takih/ [takix] 'after', a uvular [x], e.g. /cikah/

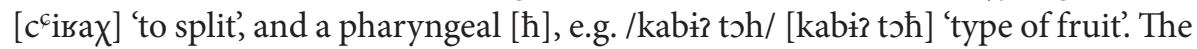
voiced fricative allophones include the pharyngeal [s], e.g. /hah/ [saћs] 'mouth' and the glottal [h], e.g. /hah/ [hax] 'mouth'. There appear to be no strict distributional patterns in these realisations, and the same word can be pronounced in multiple ways. However, one observable tendency is that the pharyngeal and uvular realisations seem to occur mainly following the open vowels /a, o/. In the coda of a reduplicated syllable as well as across word boundaries, particularly if followed by a palatal or alveolar consonant, the phoneme is sometimes realised as a palatal fricative, e.g. /chcoh/ [ $\mathrm{c}^{\complement} \mathrm{a} \mathrm{cc}^{\complement} \mathrm{sh}$ ] 'to tell untruths', /bah den/ [baఢ $\mathrm{d} \varepsilon^{9}$ y] 'go and look'. If followed by the alveolar stop $/ \mathrm{t} /$, reduplicated $/ \mathrm{h} /$ is occasionally realised as a glottal stop [?], e.g. /tıhtũh/ [tõ?tũh] 'wrinkled hornbill (Rhyticeros corrugatus)'.

Also, infrequently in sequences consisting of $/ \mathrm{h} /+$ nasal, $/ \mathrm{h} /$ undergoes assimilation and surfaces as a voiceless nasal, e.g. /hmur/ [mmur] 'group, collection'

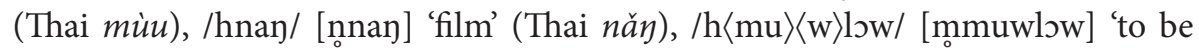
yelling' (derived form of /halow/, from Malay halau), /hninien/ [nninien] '(bird sp.)' (cf. below).

3.1.3.1 Note on $/ h /+$ sonorant sequences. A subset of the Thai loans where the source term begins with a sonorant are realised in Maniq with a sequence of $/ \mathrm{h} /$ + the sonorant, e.g. /hmur/ 'group, collection' (Thai mùu), /hnay/ 'film' (Thai năy), /hlek/ 'iron' (Thai lèk), /hwan/ 'sweet' (Thai wăan), /hjã/ 'grass' (Thai yâa). Interestingly, these sonorant segments are reconstructed as voiceless in Proto-Tai, i.e. ${ }^{* h} \mathrm{~m},{ }^{* h} \mathrm{n},{ }^{* \mathrm{~h}} \mathrm{l},{ }^{\star \mathrm{h}} \mathrm{w}$ (Pittayaporn 2009), indicating that present-day Maniq shows reflexes of the earlier stage of pronunciation of the Thai source terms (Diffloth, personal communication). This pattern provides clues to the age and source of Thai borrowings in Maniq: voiced/voiceless distinction in sonorants existed in Old Thai but not Modern Thai and the merger and associated loss of voiceless sonorants occurred around $1600 \mathrm{AD}$ at the latest (Li 1977). We can thus cautiously propose this date as a terminus ante quem for Maniq (and Aslian) contact with Thai.

\subsubsection{Liquids}

The lateral /1/ occurs syllable-initially, realised as an apico-alveolar lateral [1]: /lic/ [lic] 'ant', /planuk/ [planuk $\left.{ }^{\mathrm{i}}\right]$ 'lesser mouse deer (Tragulus kanchil)', /hlatõt/ [hlãtr̃̃t] 'to be sticky'. Word-finally, [1] is in free variation with the palatal glide [j]: 
/təmkal/ [təmkal təmkaj] 'man, husband', /pitul/ [pitul pituj] 'to put in', /naral/ [naral naraj] 'morning, tomorrow'. In most cases, individual speakers show a preference for one final allophone, but other speakers use them interchangeably. The palatal realisation neutralises the contrast with the actual phoneme $/ \mathrm{j} / \mathrm{in}$ some minimal pairs: /karel/ [karej] 'pot' vs. /karej/ [karej] 'thunder deity', /kul/ [kuj] 'to shout' vs. /kuj/ [kuj] 'head'. However, such pairs are not numerous and context usually resolves possible ambiguities.

The rhotic/r/ occurs syllable-initially in a limited number of Thai loanwords and indigenous Aslian terms. This sound is phonetically unstable across many Aslian languages. Also in Maniq it displays considerable allophonic variation and is varyingly realised as a uvular trill [R], e.g. /rop/ [Rэp $\left.{ }^{\phi}\right]$ 'to fight' (Thai róp); a velar

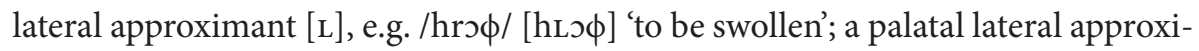
mant $[K]$, e.g. /ran/ [ $\left.K^{j} \mathrm{a}^{\mathrm{d}} \mathrm{n}\right]$ 'shop' (Thai ráan); or a velarised lateral approximant [1], e.g. /ruc/ [łoc] 'liver'. However, it is never realised as the alveolar trill [r] typical of some Aslian languages. Since the set of examples is very limited, it is not possible to determine at this stage whether the different allophones are conditioned by the environment or if they are in free variation. None of these realisations appear to be more common or fundamental than any other. Given the variation in place of articulation, we therefore prefer to render this phoneme as $/ \mathrm{r} /$. Also, comparing Maniq forms with those of other Aslian languages, we have observed that Maniq /r/ typically corresponds to $/ \mathrm{r} /$ in those languages. This suggests there is also a historical motivation for representing it underlyingly as $/ \mathrm{r} /$. However, in some forms, Aslian /r/ corresponds to a glottal stop or nothing in Maniq, e.g. /karej/ [karej]

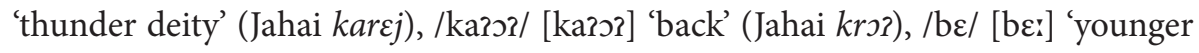
sibling' (Jahai ber), /hakot/ [hakot] 'night' (Jahai hrkit). This glottal stop is not in complementary distribution or free variation with other realisations of $/ r /$ and is thus not considered here to be an allophone of $/ \mathrm{r} /$.

\subsubsection{Approximants}

The approximant /w/ occurs in syllable-initial and syllable-final position and is realised as a voiced bilabial [w]: /wa/ [wa:] 'to walk, to go', /balaw/ [bslaw] 'blowpipe', / cawe/ [ cawe:] 'to search'. If uttered slowly in isolation, a word with a final /w/ is sometimes pronounced with a voiceless off-glide, e.g. /kawaw/ [kıwaw ${ }^{M}$ ' bird'.

The approximant $/ \mathrm{j} /$ is found both syllable-initially and syllable-finally. In both positions it is most often realised as a voiced palatal [j], e.g. /d jj/ [d jj] 'to come', /gəjah/ [gəjah] 'elephant', /jek/ [jek] 'to return'. Sometimes, if a form is uttered in isolation or emphasised, an affricate realisation [b] occurs in the onset of the ini-

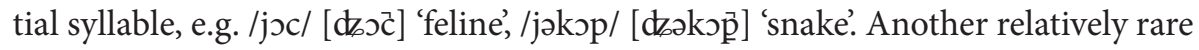
realisation of /j/ employed in fast speech is the voiced palatal fricative [j], e.g. /jin/

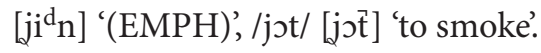




\subsection{Vowels}

Aslian vowel inventories typically involve a basic monophthongal three-by-three system of vowel heights and front-back qualities, cross-cut by an oral-nasal distinction. Some languages expand this system of basic qualities by adding a twoway length or register distinction, an extra height, or diphthongs (cf. Kruspe 2004:58-59).

Maniq adheres to the basic Aslian pattern. The data analysed to date suggest three degrees of vowel height and three degrees of front/back distinction for oral vowels. All oral vowel phonemes apart from the mid-front and mid-back have nasal phoneme counterparts. As in most Aslian languages, these are significantly less frequent than the oral ones. Two additional vocalic nuclei are represented by the opening diphthong /ie/ and its nasal counterpart/ĩe//. This provides a total number of 18 distinctive vocalic nuclei. The full system is presented in Table 2.

Table 2. Distinctive vocalic nuclei in Maniq

\begin{tabular}{|c|c|c|c|c|c|c|}
\hline & \multicolumn{3}{|c|}{ ORAL } & \multicolumn{3}{|c|}{ NASAL } \\
\hline & front & central & back & front & central & back \\
\hline high & $\mathrm{i}$ & $\dot{\mathrm{t}}$ & $\mathrm{u}$ & $\tilde{\mathbf{1}}$ & $\tilde{\mathbf{1}}$ & $\tilde{\mathrm{u}}$ \\
\hline close-mid & e & & o & & & \\
\hline open-mid & $\varepsilon$ & $\partial$ & o & $\tilde{\varepsilon}$ & $\tilde{\partial}$ & $\tilde{\jmath}$ \\
\hline open & & $\mathrm{a}$ & & & $\tilde{a}$ & \\
\hline diphthongs & & & & & & \\
\hline
\end{tabular}

Typically for a Northern Aslian language, Maniq does not have contrastive vowel length. Environmentally-conditioned lengthening takes place in final open-syllable vowels and typically occurs when words having this structure are uttered in isolation or appear in a focus position such as the end of a phrase, e.g. [wa: /wa/ 'to walk, to go'.

The following near-minimal set illustrates the contrasts between the vowel qualities in the basic three-by-three system:

Table 3. Vowel contrasts in Maniq

\begin{tabular}{|c|c|c|}
\hline /kapin/ 'on, up' & /campiç/ 'to be sick' & /baju?/ 'shirt' \\
\hline /calak pen/ '(lizard sp.)' & /lсpә६/ 'to be fragrant' & $\begin{array}{l}\text { /kajo?/ 'Sunda flying lemur (Galeopterus } \\
\text { variegatus)' }\end{array}$ \\
\hline /pnpen/ 'cheek' & /canbãn kapac/ '[toponym]' & /kijos/ 'to turn one's back to someone' \\
\hline
\end{tabular}


Importantly, the Maniq system does not bear any resemblance to that proposed for the closely related Northern Aslian language Kensiw with five degrees of height for front and central vowels, and four for the back vowels (Bishop 1996). The Kensiw system displays a level of quality variation which is hardly observed even at the phonetic level in other Aslian languages, and Benjamin (2012) cautiously questions the analysis. Phaiboon (1984) documents a typical three-by-three system for the same variety, and Asmah (1963) describes a system of eight qualities (three degrees of height for front and back, and two for central) for the similarly closely related variety Kentaq. Our own Kentaq data suggest a typical three-by-three system with nine oral vowels, seven of which have nasal counterparts (Burenhult, field notes, 2005).

\subsubsection{Phonetic description of vowels}

/i/ - is a close front unrounded vowel [i]: [manir] /maniz/ 'indigenous person'; its nasal counterpart is realised as [ĩ]: /batĩk/ [bãtĩk] 'to be dirty'.

/e/ - is a close-mid front unrounded vowel [e]:/2ijen/ [ iije $^{9} \mathrm{n}$ ] 'bone'; in the context of palatals, it is in free variation with the near-close unrounded [I]:/6ec/ [sIC]] 'meat', and a raised [e]: / kajen/ [kejes $\left.{ }^{9} \mathrm{n}\right]$ 'to hear, to listen'.

$/ \varepsilon /$ - is an open-mid front unrounded vowel $[\varepsilon]$ : /bem/ [be $\left.\varepsilon^{b} \mathrm{~m}\right]$ 'many'; in the con-

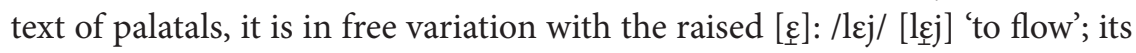

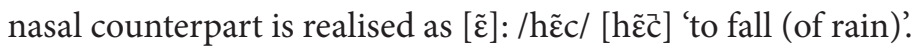

/ì - is a close central unrounded vowel [i]]: /kabì// [kabì?] 'fruit', slightly lower than other high vowels, sometimes realised as the close back unrounded vowel [u]:

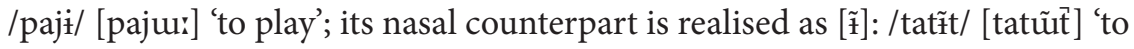
make a sound (of porcupine)'.

$/ ə /$ - is a mid central unrounded vowel [ə]: / /anten dəl/ [ [ant $\varepsilon^{9} \mathfrak{n}$ dəl] 'to be deaf'; its nasal counterpart is realised as [ã]: /dagãn/ [dagãn] 'charcoal'.

/a/ - is an open central unrounded vowel [a]: /tak/ [tak] 'to cook in water', in the pre-final syllable $[\mathrm{a}]$ is in free variation with $[\mathrm{e}]$ and $[\Lambda]: / \mathrm{kacer} /\left[\mathrm{kec}^{\complement} \mathrm{er}\right]$ 'moon', /jampih/ [jımpix] 'to fall'; its nasal counterpart is realised as [ã]: /lapãk/ [lãpãk]] 'mud'.

$/ \mathrm{u} /$ - is a close back rounded vowel [u]: / rankut/ [rankut] 'to lift', occasionally realised as the near-close back rounded [v]: /ruc/ [łoc] 'liver'; its nasal counterpart is realised as [ũ]: /katũt/ [katũ̃ ] 'protrusion'.

/o/ - is a close-mid back rounded vowel [o]: /takop/ [takop̉] 'tuber (Dioscorea orbiculata)'.

$/ \supset /$ - is an open-mid back rounded vowel [0]: / $6 \supset 3 /$ [6ว?] 'to be dead'; it is in free variation with a less frequent open back rounded [v]: /won/ [w $\left.w^{9} \mathrm{n}\right]$ 'small'; its

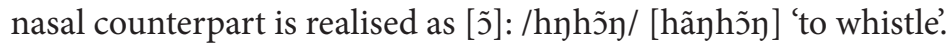

/ie/ - is an opening diphthong [ie] with a close-to-mid articulation: /galiet/ [galiet] 'to be tired'; its nasal counterpart is realised as [ĩẽ]: /bagĩẽc/ [bãgĩẽc] 'to be red'. 


\subsubsection{Nasal and nasalised vowels}

Like for other Aslian languages, it is important to make a distinction in Maniq between nasal vowels, i.e. those which are characterised by phonemic nasality, and nasalised vowels, i.e. those which display phonetic nasalisation conditioned by the environment. Nasality can usually be straightforwardly distinguished from nasalisation.

3.2.2.1 Nasal vowels. Phonemically nasal vowels occur only in the final syllable. They are significantly less frequent than oral vowels. The following minimal or near-minimal pairs illustrate the contrastive function of the nasal vowel series:

\begin{tabular}{|c|c|c|c|}
\hline / & 'to sneeze' & $|\mathrm{t} \varepsilon \varphi|$ & 'to sever a rigid object' \\
\hline /batĩk/ & 'to be dirty' & /patik/ & 'to miss a target' \\
\hline /ckcãk/ & $\begin{array}{l}\text { 'to make a sound } \\
\text { (of footsteps in mud)' }\end{array}$ & /ckcak/ & 'to dim, to wane (of moon)' \\
\hline /dagãn/ & 'charcoal' & /dəgen/ & $\begin{array}{l}\text { 'beautiful tree squirrel } \\
\text { (Callosciurus sp.)' }\end{array}$ \\
\hline /mahĩm/ & 'blood' & /tahim/ & 'dung beetle' \\
\hline /hitว̃t/ & 'to attach' & /tot/ & 'to burn, to roast' \\
\hline$/ \mathrm{ka}$ & 'protrusion' & /tut/ & 'to be empty' \\
\hline /lak & 'to be thin, to be fine' & /lakiem/ & 'brain' \\
\hline
\end{tabular}

3.2.2.2 Nasalised vowels. Phonetic nasalisation of vowels is conditioned by nasal vowels and nasal consonants. It is bidirectional, i.e. both progressive and anticipatory. There is a tendency for nasal vowels to cause anticipatory nasalisation of the vowel of a preceding syllable, e.g. /hitว̃t/ [hĩtว̃t] 'to attach something', /bagĩẽc/ [bãgĩẽc] 'to be red', /harît/ [hã̃ît] 'to stink', /pawĩc/ [pãwĩ̄c] '(turtle sp.)'. In most Aslian languages this type of nasalisation occurs only with a limited set of intermediate consonants (typically approximants and glottals, cf. Burenhult 2005). In Maniq, however, all consonants are transparent to such nasalisation.

\subsubsection{Diphthongs}

The opening diphthongs /ie/ and /ĩe/ are found in a limited set of lexical items and are contrasted below with monophthongs:

$\begin{array}{llll}\text { /tier/ } & \text { 'soil' } & \text { /ter/ } & \text { 'mortar' } \\ \text { /paliek/ } & \text { 'to be white' } & \text { /palik/ } & \text { 'bat' } \\ \text { /talien/ } & \text { 'Pinanga sp. } & \text { /jaksp talen/ } & \text { 'snake sp.' } \\ \text { /kamien/ } & \text { 'lower leg, shin' } & \text { /kamen/ } & \text { 'to be young' } \\ \text { /biem/ } & \text { 'gular sac' } & \text { /bem/ } & \text { 'to be many' } \\ \text { /kapiẽh/ } & \text { 'to have small } & \text { /kapĩh/ } & \text { 'to have a small hole and } \\ & \text { nostrils' } & & \text { thick walls (of bamboo)' }\end{array}$


Diphthongs are not a pan-Aslian feature, but occur in some languages, and the question arises if the Maniq examples reflect innovation or retention. Some comparative evidence shows that Maniq diphthongs may correspond to diphthongs in occasional distant relatives, which suggests that they are a conservative feature of the Maniq sound system. Comparative examples include Maniq /tiek/ 'to sleep, to lie down' and Jah Hut /cyek/ 'to sleep' (Diffloth 1976); ${ }^{7}$ and Maniq /lakiem/ 'brain' and Semnam /lakuo:m/ 'brain' (Burenhult \& Wegener 2009).

Thai words containing the diphthong $i a$ are borrowed into the Maniq system with the opening diphthong/ie/. Examples include /lonien/ 'school' (Thai rooyrian), / $\mathrm{t}^{\mathrm{h}} \mathrm{ien} /$ 'candle' (Thai thian), /bie/ 'money' (Thai bîa), and /hut $\mathrm{H}_{\mathrm{h}} \mathrm{iem} /$ 'garlic' (Southern Thai hǔa thîam).

\subsection{Prosodic features}

\subsubsection{Stress}

Like in other Aslian languages stress has no lexically contrastive function in Maniq and falls invariably on the final syllable. Furthermore, no secondary stress has been found. Thai loans receive stress on the final syllable, consistent with the stress patterns in both Maniq and Thai (Haas 1964).

\subsubsection{Tone}

We have found no evidence of retained tones for systematic contrast in Maniq, neither in the borrowed nor the indigenous lexicon. Maniq speakers, who are fluent in Southern Thai, are aware of tonal distinctions in that language and, not surprisingly, in the context of elicitation carried out in Thai, they often pronounce borrowed items in a Thai-like manner. However, Thai loanwords are not realised consistently with the same pitch. Peterson (2012:23, fn 7) makes the same observation. This is true not only of the same items in different prosodic contexts, but

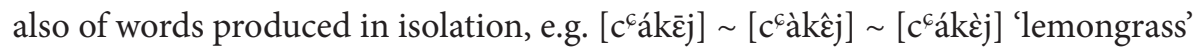

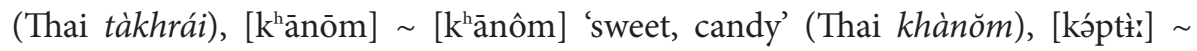

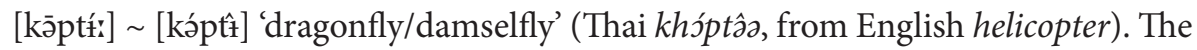
examined items are also not marked by distinct phonation. Moreover, speakers of Maniq accept realisations of the same items with varying pitches and, when asked explicitly whether there is a difference between these realisations, state that there is none. It is therefore evident that tone is not retained as a contrastive feature in items borrowed from Thai.

As for indigenous vocabulary, we have examined items most likely to reveal tonal distinctions: (1) words transcribed as homophones (e.g. / cak/ [cak] 'to wash clothes' (Thai sák), /cak/ [cak] 'old tuber'), (2) cognates of what are said to be contrastive tonal pairs in closely related $\mathrm{Kensiw}^{8}$ (/kuj/ 'head', /kec/ 'to cut', and 
/kap/ 'to bite'; cf. Bishop 1996), and (3) stop-initial pairs with unexpected variation in voicing (e.g. /gaw/ [gaw] [kaw] 'pig' and /kaw/ [kaw] [gaw] '(proximate marker)'). In all cases, the words in question are not consistently realised with the same pitch, but rather the pitches vary considerably across different realisations, suggesting that they convey post-lexical information and are not part of the underlying representation. In addition, Maniq speakers accept realisations of the same words with varying pitches and, for homophones, confirm that items in homophonic sets are pronounced the same.

To summarise, we are unable to distinguish lexically contrastive tonal patterns in Maniq, even amongst the items that would be most likely to carry them. We think it is significant that existing tonal contrasts in Thai, of which the Maniq are aware, are lost when Thai items are borrowed into Maniq. Equally significant is the fact that speakers' judgments of items with varying pitches consistently support our impression that tone is not lexically contrastive.

\section{Discussion}

\subsection{Consonants}

The Maniq consonant system is fundamentally Aslian in character, and typically Northern Aslian at that, with its addition of the bilabial fricative to the standard basic set of distinctions. However, its additional series of aspirated stops is rare in the Northern Aslian context, and is also not typical for Aslian in general. As demonstrated, these consonants are infrequent and restricted to Thai loan words. It is thus doubtful whether they should be considered fully integrated components of Maniq phonology. We can conclude that Maniq does not display any of the indigenous manifestations suggested to occur in Kensiw (Hajek 2010). This means that a component considered fundamental to the development of tonal distinctions is absent (see further in Section 4.4).

The aspirated stop series looks superficially similar to the equivalent series described for Southern Aslian Mah Meri by Kruspe \& Hajek (2009). It might be tempting to ascribe these similarities to either shared retention of archaic distinctions largely lost elsewhere in Aslian, or some common historical contact situation. However, we can conclude that the two languages have acquired these distinctions in very different and unrelated ways. Whereas the Maniq series is restricted to Thai borrowings and thus of evidently foreign origin, the Mah Meri aspirated stops are a Southern Aslian feature.

Our decision to analyse the bilabial aspirated stop in indigenous forms as the syllable-initial allophone of the bilabial fricative $/ \phi /$ calls for elaboration. This 
phoneme is restricted to the Maniq-Menraq/Batek branch of Northern Aslian, and has so far only been found in syllable-final position. It is a very unusual phoneme from an areal point of view (cf. Diffloth 1975:5). As noted, it is also highly iconic and associated with a particular class of meanings. Furthermore, it is the most infrequently occurring consonant in the languages in which it exists - for example, our present Maniq word list of 2,100 forms contains only 20 forms with $/ \phi /$; Bishop \& Peterson's (1993) Kensiw glossary of 2,170 entries contains 13 . The presence of a syllable-initial allophone of $/ \phi /$ in Maniq not only places it distributionally on a par with the other fricatives in the language. It also speaks to an areally unusual tendency in many Aslian languages for greater tolerance of both initial and final exponents of consonant phonemes (cf. Benjamin's 1976 description of final voiced and voiceless stops in Temiar, a distinction which is almost unheard of elsewhere in Southeast Asia). The discovery occasions a search for similar allophones which may have passed unnoticed in other Northern Aslian languages.

From an Aslian perspective, the most idiosyncratic aspect of the Maniq sound system is its high degree of variation in the realisation of consonants. Some types of conditioned variation, such as the prestopping of word-final nasals after oral vowels or the typically unreleased character of word-final stops, are common among Aslian languages. But for the most part the conditioned and free variation observed in Maniq is prominent compared to that described for other Aslian languages. Most notably, stops are affricated, fricativised, or even approximatised; the voiceless alveolo-palatal fricative $/ \varsigma /$ can be realised as voiceless affricates or a voiced approximant; and the apico-alveolar lateral /l/ can surface as [j] word-finally. These are mostly processes of lenition (e.g. voicing, affrication, spirantisation, and approximation), although fortition seems to be in evidence as well (e.g. the affricate realisations of the voiceless alveolo-palatal fricative $/ \epsilon /$ ). Clearly the Maniq consonant system is characterised by a measure of instability so far not observed in other Aslian settings (see Sections 4.4 and 5 below for further discussion).

\subsection{Vowels}

The basic system of contrasting vowel qualities in Maniq is consistent with those encountered in a number of other Aslian languages, and the contrast between oral and nasal vowels is shared with almost all of them. Like other Northern Aslian languages, but unlike Central Aslian languages, Maniq does not have contrastive vowel length. It preserves diphthongal distinctions with clear correspondences in some other Aslian languages. There is nothing to indicate that Maniq displays an unusual system of qualities of the kind proposed for Kensiw (Bishop 1996). Consequently, as far as vowels are concerned, we have no reason to conjecture nonAslian influence on contrastive strategies, nor any major internal reorganisation. 


\section{$4.3 / \mathrm{h} /+$ sonorant sequences}

As noted, $/ \mathrm{h} /+$ sonorant sequences in some Thai loans indicate that Maniq borrowed vocabulary from Old Thai and that a terminus ante quem for Thai contact of $1600 \mathrm{AD}$ can be proposed on those grounds. Incidentally, our own phylogenetic and phylogeographic models of Aslian history suggest that Maniq split off from its sister branch Kensiw/Kentaq some several hundred years ago (Dunn, Kruspe \& Burenhult 2013). Similar /h/ + sonorant sequences in Thai loans have not been reported in these varieties, so this may be taken to indicate that Maniq is the only surviving Aslian language to have experienced early and sustained contact with Thai.

\subsection{Tone}

Our analysis has been unable to detect lexical tone in Maniq, even in Thai borrowings, and we believe no such contrast exists. Considering the distinctive contact ecology of Maniq, this result may have a significant bearing on the issue of tone in Northern Aslian. The tonal tendencies observed in previous work are linked to unstable realisation of initial stops (cf. Hajek 2003), a well-documented tonogenetic phenomenon in other branches of Austroasiatic (Svantesson 1989). Specifically, the merging of voiceless aspirated and unaspirated stops tends to be associated with high tone and the voiced stops with low tone. However, as we have demonstrated, Maniq does not bear traces of indigenous aspirated stops, its voicing contrast in initial stops remains (despite the variation), and tonal or register patterns have not developed into a strategy of lexical contrast. Given Bishop's (1996) and Phaiboon's (1984) first-hand analyses, as well as our own limited Kensiw data, we propose that a similar situation holds for Kensiw. Although the processes we observe are certainly relevant to the conditioning of pitch differences, we believe that the proposed contrastive function of tone and aspiration in Northern Aslian is overstated.

Our Maniq data also demonstrate that the marginal instability of voicing in initial stops forms part of a much broader trend of flux and variation in the indigenous consonant system. Thus, to the extent that we are witnessing pitch differences of some sort, there does not seem to be a simple one-to-one causal relationship between a merging stop series and tonal development. This is a crucial point when we consider any potentially tonogenetic processes. Specifically, it is difficult to argue that contact with tonal Thai has somehow stimulated the unstable realisation of stops (cf. Hajek 2003). It is also noteworthy in this context that some Southern Thai varieties are currently undergoing their own tonogenetic processes, through which a new high tone is evolving in tandem with lenition of final stops (Diller 1982; Diller 1985). This development is qualitatively different from the processes 
proposed for Northern Aslian by Hajek (2003) because it results from regressive conditioning of register on the basis of finals, rather than progressive conditioning on the basis of initials. Note again that the realisational variation of consonants in Maniq mainly affects initials, not finals. In short, the Maniq consonant system offers no evidence of contact-induced changes which could stimulate the development of lexical tone.

\section{Concluding remarks}

Maniq strategies of phonological contrast are manifestly Aslian. The segmental systems are typical of its genealogical grouping, and register and tone are not lexically contrastive. In this respect, Maniq shares fully in the distinctiveness of Aslian languages and does not follow the typological trends of Mainland Southeast Asia, in spite of its geographical exposure. We propose that existing claims of contrastive aspiration and tone in Northern Aslian (Hajek 2003, 2010) are in need of careful reassessment.

What does make Maniq unusual in the Aslian context is its penchant for variation in the realisation of consonants, especially far-reaching and unpredictable manner variability in initials in the form of lenition. Environmental conditioning seems to play only a minor role, since a given form typically displays realisational instability across both occurrences and speakers. The rationale of this inter- and intra-individual elasticity remains to be charted, but it is clear that it is extreme when compared to the allophonic variation documented in other Aslian languages.

The patterns of free variation identified here represent rather significant departures from mainstream Aslian phonology. Failing to find clear evidence that these developments are conditioned by the distinct 'Mainland' contact ecology of the language, we propose instead that the issue should be viewed in light of a different set of sociolinguistic parameters. First, the Northern Aslian speech communities in general (and especially those of the Semang forager sphere) display a distinct and well-documented pattern of idiolectal variation and change (Benjamin 1985a: 234-5). This is due to their highly mobile lifestyle, manifested in their system of intermarriage between individuals of widely dispersed groups, as well as in their marked pattern of group disintegration and regrouping into new constellations as an adaptive response to ever-changing subsistence conditions. This spatial and social mobility, and presumably the associated patterns of idiolectal variation, are most pronounced in the northern parts of their range (Benjamin 1985a:243-4, 261-2). Maniq here represents the northernmost extreme.

Second, and crucially, Maniq is geographically disconnected from its Aslian relatives and not in social contact with them. This sets it apart from the other 
Northern Aslian communities, which, in Benjamin's (1985a) terms, form a "mesh" of inter-varietal contact in which individuals intermarry, move, and acquire new languages. So, while the Maniq communities display the typical Northern Aslian spatial and social flexibility, they lack the component of inter-Aslian contact and multilingualism. This lack, coupled with the fact that the Maniq community is small (c. 300 speakers) and fragmented, may well foster a high degree of phonological idiosyncrasy and variability, as well as an increased rate of change. It is well-known that small and tight language communities, where communication is constantly face-to-face and knowledge is profoundly shared, have a tendency to tolerate high levels of linguistic irregularity and complexity (see e.g. Kusters 2003). Arguably, the highly individualistic language use appreciated in the foraging Northern Aslian communities enforces this pattern even more. Our analyses of basic vocabulary suggest that the same circumstances may have spawned an unusually high rate of lexical change in Maniq (Dunn et al. 2011), and we might speculate that it is a recurrent typological pattern throughout the Maniq language system.

While retaining typically Aslian strategies of phonological contrast, the Maniq sound system bears witness to developments which have so far not been documented in other Aslian languages. This points to hitherto unrecognised paths of diversification within Aslian and hints at interesting typological discoveries to be made in our continued exploration of the Maniq language. We believe these developments are primarily conditioned by the distinctive social ecology and geographical isolation of the Maniq community, not by contact with Thai.

\section{Notes}

* The present work is based on field research carried out intermittently from 2009 to 2014 by Wnuk among speakers of Maniq in Satun Province, Thailand. It forms part of a wider program of description and documentation of Maniq carried out by Wnuk (in progress), and it is the first in-depth examination of Maniq language structure. We are grateful to the Maniq community of Manang (Satun), Jaroon Thotsagool, the National Research Council of Thailand, Suwilai Premsrirat, and Theraphan Luangthongkum. Special thanks goes to Norval Smith for his supervision of an earlier version of the phonological analysis. We thank Nicole Kruspe, Stephen Levinson, Nick Enfield, Sylvia Tufvesson, Gérard Diffloth, Geoffrey Benjamin, JanOlof Svantesson, Asifa Majid, the editors, and two anonymous reviewers of Studies in Language for insightful comments on the earlier drafts of this article. Thanks also go to Michael Dunn, Paul Boersma, and Jan-Willem van Leussen. The research leading to these results was supported by the Volkswagen Foundation's DOBES program (Wnuk and Burenhult), the Max Planck Gesellschaft (Wnuk), and the European Research Council under the European Union's Seventh Framework Programme (FP7/2007-2013)/ERC Grant agreement no. 263512 (Burenhult). 
1. There is also a Maniq group in the Rattaphum District, Songkhla province. Although there are no linguistic data available, it is likely that they speak the same language. The population estimate is based on a survey carried out by Wnuk in 2009. The term Maniq is adopted here in accordance with the speakers' own usage to refer to a specific language variety, but it is not entirely unproblematic. Previous literature on this variety contains several alternative names, including Tonga and Mos (used e.g. by Schebesta \& Blagden 1926; Bishop \& Peterson 2003), Trang Kensiw (Bauer 1991), and Tean-ean (Phaiboon 2006), Ten-edn (Peterson 2012) or Ten'en (Dunn et al. 2011). None of these alternative names is known to the consultants whose variety is discussed here.

2. Maniq phonotactics are not dealt with in detail in this paper, but we would like to briefly point out that they largely conform to the general Aslian pattern, e.g. most phonemic variation is found in the final syllable, all syllables start with a consonant, the inventory of initials is larger than that of finals (see, for instance, Kruspe 2004:58-60). Unlike some other Aslian languages, Maniq allows final open syllables.

3. The only possible exception here is the word / $a t^{\mathrm{h}} \tilde{u} \mathrm{t} /$ 'to be short, to be stumped' most likely deriving from the Malay kontot 'stumpy, clipped, maimed'.

4. Nasal segments in Maniq cause both progressive and anticipatory nasalisation, which are predictable and not marked for the most part of this paper. Only where it facilitates an illustration of various related processes is nasalisation included in the phonetic orthography.

5. Prestopped nasals are a common Aslian phenomenon featured in many descriptions and cross-Aslian studies (for a summary of the topic, see e.g. Benjamin, 2012:27-28).

6. This minimal pair is an example of a consonantal template, often found with perceptual verbs in Maniq (and common with Semai expressives, Tufvesson 2011). The two forms share the string of consonants, which defines the perceptual notion (in this case, hollowness, having small holes) common for both of them, while the alternating vocalic nucleus provides the particulars of that notion. For more examples of templates, see Tufvesson 2011.

7. The Jah Hut item is given in Diffloth's original notation. Although it diverges from the one adopted in this paper, it stands for the same opening diphthong /ie/.

8. In addition to tone, the initial consonants in the discussed examples differ in terms of being fortis/lenis (Bishop 1996). This suggests that we could be dealing with a consonantal rather than a tonal contrast. This interpretation is backed by Phaiboon's (1984) analysis of tonal patterns in the same variety of Kensiw, stating that tone has no contrastive function there. Indeed, Bishop herself acknowledges that the pitch differences are minimal and atypical and states that Kensiw is not a tonal language $(1996: 239)$.

\section{References}

Asmah Haji Omar. 1963. Bahasa Semang: Dialek Kentakbong. University of Malaya unpublished honours thesis. 
Bauer, Christian. 1991. Kensiw: A Northern Aslian language of southern Thailand. In Surin Pookajorn (ed.), Preliminary report of excavations at Moh-Khiew Cave, Krabi Province, Sakai Cave, Trang Province and ethnoarchaeological research of huntergatherer group, socall "Sakai" or "Semang" at Trang Province, 310-335. Bangkok: Silipakorn University, Faculty of Archaeology.

Becker, Neele. 2008. DoBeS archive: Semang. IMDI-corpora. http://corpus1.mpi.nl/ds/imdi_ browser/ (22 October 2012).

Benjamin, Geoffrey. 2012. The Aslian languages of Malaysia and Thailand: An assessment. In Peter K. Austin \& Stuart McGill (eds.), Language Documentation and Description, vol. 11. London: Endangered Languages Project, School of Oriental and African Studies.

Benjamin, Geoffrey. 1976. An outline of Temiar grammar. In P. N. Jenner, L. C. Thompson \& S. Starosta (eds.), Oceanic Linguistics Special Publications, Part I: 129-188. Honolulu: The University Press of Hawaii.

Benjamin, Geoffrey. 1985a. In the long term: Three themes in Malayan cultural ecology. In Karl L. Hutterer, A. Terry Rambo \& George W. Lovelace (eds.), Cultural Values and Human Ecology in Southeast Asia, 219-278. University of Michigan: Center for South and Southeast Asian Studies.

Bishop, Nancy. 1996. A preliminary description of Kensiw (Maniq) phonology. Mon-Khmer Studies 25. 227-254.

Bishop, Nancy \& Mary Peterson. 1993. Kensiw glossary. Mon-Khmer Studies 23. 163-195.

Bishop, Nancy \& Mary Peterson. 1993. Maniq language survey report. Bangkok: TU-SIL-LRDP Thammasat University.

Bishop, Nancy \& Mary Peterson. 2003. Northern Aslian language survey: Trang, Satul and Phatthalung provinces, Thailand. Bangkok: TU-SIL-LRDP Thammasat University.

Burenhult, Niclas. 2005. A Grammar of Jahai. Canberra: Pacific Linguistics.

Burenhult, Niclas, Nicole Kruspe \& Michael Dunn. 2011. Language history and culture groups among Austroasiatic-speaking foragers of the Malay Peninsula. In N. J. Enfield (ed.), Dynamics of human diversity: The case of mainland Southeast Asia, 257-277. Canberra: Pacific Linguistics.

Burenhult, Niclas \& Claudia Wegener. 2009. Preliminary notes on the phonology, orthography and vocabulary of Semnam (Austroasiatic, Malay Peninsula). Journal of the Southeast Asian Linguistics Society 1. 283-312.

Diffloth, Gérard. 1975. Les langues mon-khmer de Malaisie: Classification historique et innovations. Asie du sud-est et monde insulinde 6(4). 1-19.

Diffloth, Gérard. 1976. Jah-Hut, an Austroasiatic language of Malaysia. In Nguyen Dang Liem (ed.), South-East Asian Linguistic Studies, vol. 2, 73-118. Canberra: Pacific Linguistics.

Diffloth, Gérard \& Norman H. Zide. 1992. Austro-Asiatic languages. In William Bright (ed.), International encyclopedia of linguistics, vol. 1, 137-42. New York: Oxford University Press.

Diller, Anthony. 1982. A New High Tone in Southern Thai. Papers in South-East Asian linguistics 8. 133-54.

Diller, Anthony. 1985. High and Low Thai: views from within. In David Bradley (ed.), Papers in Southeast Asian linguistics, vol. 9, 51-76. Australian National University: Pacific Linguistics.

Dunn, Michael, Niclas Burenhult, Nicole Kruspe, Neele Becker \& Sylvia Tufvesson. 2011. Aslian linguistic prehistory: A case study in computational phylogenetics. Diachronica 28. 291323. DOI: $10.1075 /$ dia.28.3.01dun 
Dunn, Michael, Nicole Kruspe \& Niclas Burenhult. 2013. Time and place in the prehistory of the Aslian languages. Human Biology 85. 383-399. DOI: 10.3378/027.085.0318

Haas, Mary R. 1964. Thai-English student's dictionary. Stanford, CA: Stanford University Press. Hajek, John. 2003. Evidence of tonal activity in Aslian. Mon-Khmer Studies 33. 59-66.

Hajek, John. 2010. Aspiration in some varieties of northern Aslian. Oceanic Linguistics 49(2). 359-368.

Kruspe, Nicole. 2004. A Grammar of Semelai. New York: Cambridge University Press.

Kruspe, Nicole. 2010. A Dictionary of Mah Meri as spoken at Bukit Bangkong (Oceanic Linguistics Special Publication 36). Honolulu: University of Hawaii Press.

Kruspe, Nicole, Niclas Burenhult \& Ewelina Wnuk. In press. Northern Aslian. In Paul Sidwell \& Mathias Jenny (eds.), Handbook of Austroasiatic Languages. Leiden: Brill.

Kruspe, Nicole \& John Hajek. 2009. Mah Meri. Journal of the International Phonetic Association 39. 241-248. DOI: 10.1017/S0025100309003946

Kusters, Christiaan Wouter. 2003. Linguistic complexity: The influence of social change on verbal inflection (LOT Dissertation Series). Utrecht: LOT.

Ladefoged, Peter \& Ian Maddieson. 1996. The sounds of the world's languages. Oxford; Cambridge, MA: Blackwell.

Li, Fang-kuei. 1977. A handbook of comparative Tai (Oceanic Linguistics Special Publication 15). Honolulu: University Press of Hawaii.

Matisoff, James A. 2003. Aslian: Mon-Khmer of the Malay Peninsula. Mon-Khmer Studies 33. 1-58.

Peterson, Mary. 2012. Notes on Ten-edn (Tonga-Mos) and Kensiw Borrowings. Mon-Khmer Studies 40. 19-34.

Phaiboon, Duangchan. 1984. A phonological description of the Kansiw language (Sakai dialect). Mahidol University MA thesis.

Phaiboon, Duangchan. 2006. Glossary of Aslian languages: The northern Aslian languages of southern Thailand. Mon-Khmer Studies 36. 207-224.

Pittayaporn, Pittayawat. 2009. The phonology of Proto-Tai. Cornell University dissertation.

Schebesta, Pater P. \& Charles Otto Blagden. 1926. The jungle tribes of the Malay peninsula. Bulletin of the School of Oriental and African Studies 4(2). 269-278.

DOI: $10.1017 /$ S0041977X00089187

Svantesson, Jan-Olof. 1989. Tonogenetic mechanisms in northern Mon-Khmer. Phonetica 46. 60-79. DOI: 10.1159/000261829

Tufvesson, Sylvia. 2011. Analogy-making in the Semai sensory world. The Senses and Society 6(1). 86-95. DOI: 10.2752/174589311X12893982233876

Tufvesson, Sylvia. Forthcoming. A grammar of perception in Semai. Nijmegen: Radboud University dissertation.

Wnuk, Ewelina. Forthcoming. Semantic specificity in Maniq verbs of perception. Nijmegen: Radboud University dissertation.

Wnuk, Ewelina \& Asifa Majid. 2014. Revisiting the limits of language: The odor lexicon of Maniq. Cognition 131. 125-138. DOI: 10.1016/j.cognition.2013.12.008 


\section{Corresponding author's address}

\section{Ewelina Wnuk}

Max Planck Institute for Psycholinguistics

Wundtlaan 1

6525 XD Nijmegen

Netherlands

ewelina.wnuk@mpi.nl 